UDK: 28:(1+32) Hattab O.

Izvorni naučni rad

Primljeno: 12.3.2019.

Prihvaćeno za štampu: 31.5.2019.

dr.sci. Sulejman Topoljak, redovni profesor

Univerzitet u Bihaću

Islamski pedagoški fakultet

sulejman.topoljak@botmail.com

\title{
PREVENTIVNE MJERE PROTIV KORUPCIJE I MITA U POLITICI I OBNAŠANJU JAVNIH FUNKCIJA U FILOZOFIJI OMERA B. EL-HATTABA
}

\section{Sažetak}

Problem korupcije u vlasti i obnašanju javnih funkcija je star koliko i ljudsko društvo i civilizacija. Svako društvo je u manjoj ili većoj mjeri na neki način iskusilo posljedice te opake drustvene bolesti jer se nije u potpunosti moglo imunizirati $i$ zaśtiti do nje. Korupcija predstavlja kontinuirani rat između dobra $i$ zla, pravde i nepravde, objektivnosti i pristrasnosti, zakona $i$ anarhije. Korupcija je jedan ogromni društveni korov - drvo sa veoma dubokim korijenom, pa je stoga nužno jedinstvo $i$ odlučnost izmedu svih pozitivnih snaga da se ono ǐ̌cupa i iskorijeni kako bi se zaštitilo čovječanstvo od njegovih smrtonosnih plodova.

Preveniranje korupcije niukom slučaju nije strano i nepoznato islamu, jer je on u osnovi vjera prevencije $i$ zaśtite. Osnovni cilj islama je pozivanje $i$ poticanje ljudi ka dobru i odvraćanju $i$ stimuliranju na udaljavanje od zla $i$ ostavljanju grijeha. Sve norme $i$ zakoni islama su isključivo i prije svega preventivna sredstva za zaštitu od zla i korupcije ili putevi koji vode ka dobru $i$ načini putem koji se postiže i realizuje. Islam je božanski sistem i program prevencije $i$ zaśtite općenito a od korupcije svih vrsta posebno cija primjena garantuje njeno sprečavanje $i$ iskorjenjivanje. Intenzitet korupcije u jednom društvu, narodu, instituciji, itd., treba isključivo posmatrati i mjeriti prema nivou usvojenosti, vjerovanju $i$ primjeni islamskih vrijednosti od strane njihovih nadredenih i podređenih. Ukoliko je korupcija intenzivna $i$ raširena u jednom drusttvu, zajednici, instituciji bez sumnje je vjera u islamske vrijednosti $i$ njihova primjena od strane navedenih oskudna ili neispravna $i$ 
obratno. To najbolje potvrduje sadašnje realno stanje korumpiranoga svijeta općenito, a posebno muslimanskog na kog otpada trećina svjetske korupcije svih vrsta po dostupnim statističkim podacima onih koji su se bavili tom problematikom. Evidentno je u cijelom svijetu da se korupcija iz dana u dan povećava, da uništava narode $i$ države i pored svih preventivnih mjera koje poduzimaju i raznih tehničkih i tehnoloških otkrića i dostignuća koja se koriste za njeno otkrivanje i sprečavanje. Očito je onda da ti lijekovi ne liječe tu društvenu bolest, nego je naprotiv samo proširuju i jačaju, što potvrduje da je dijagnoza pogrešna i da se treba ponovo uspostavljati i prema njoj nove lijekove propisivati.

Cilj ovoga rada je da praktično dokaže navedeno pravilo. Kao primjer koji će to potvrditi uzet je period vladavine drugog pravednog halife Omera b. ElHattaba, r.a., vladar koji slovi kao primjer pravde $i$ pravednosti u cijeloj historiji čovječanstva, a njegova država i vladavina, koju je uspostavio, istinski i stvarni primjer idealne države koja je bila samo prirodna posljedica primjene islamskog preventivnog sistema, tj. pravilne uspostave dijagnoze za tu opaku društvenu bolest, te propisivanja odgovarajucíh lijekova koji su prevenirali $i$ zaštitili njenu pojavu i epidemiju.

Ključne riječi: pravda, korupcija, islam, politika, prevencija, vlast, kontrola.

\section{Uvod}

Pravda je temelj opstojnosti kosmosa i jedino moralno mjerilo vrijednosti života. Pravdom je islam uslovio legalnost cjelokupnog ljudskog života. Ona je bila cilj svih nebeskih poslanica kako bi i postala temelj i osnova suđenju među ljudima. Mi smo izaslanike Naše s jasnim dokazima slali i po njima knjige $i$ terazije objavljivali, da bi ljudi pravedno postupali. (El-Hadid, 15.) Radi pravde su objavljivane sve knjige, slani svi poslanici, a na njoj počivaju nebesa i zemlja. Allah je Sebe nazvao Pravednim, distancirao se od nepravde i zabranio je ljudima. „O Moji robovi. Ja sam Sebi nepravdu zabranio pa sam je i vama zabranio pa nemojte biti međusobno nepravedni.“ (Muslim) Reci: "Ja vjerujem u sve knjige koje je Allah objavio, i naređeno mi je da vam pravedno sudim. (Eš-Šura, 15.) Pravda je u ovom ajetu uporedo spomenuta sa monoteizmom i vjerovanjem u Allaha. Islamski pravnici su pravdu spomenutu u sljedećem ajetu: Allah zahtijeva da se svačije pravo poštuje, dobro čini, $i$ da se bližnjima udjeljuje, i razvrat $i$ sve što je odvratno i nasilje zabranjuje; da pouku primite, On vas savjetuje. 
(En-Nahl, 90.) objasnili jednim generalnim objašnjenjem koje obuhvata pravedan odnos između Boga i čovjeka, čovjeka i njegove duše i čovjeka i ostalih ljudi. Prva vrsta pravde podrazumijeva preferiranje Allahovog prava i zadovoljstva nad ličnim prohtjevima i strastima, te izvršenje Njegovih naredbi i klonjenje Njegovih zabrana. Pod drugom vrstom pravde se podrazumijeva apstiniranje duše od svega onoga $u$ čemu je njeno stradanje i propast, te obuzdavanje pohlepe i zadovoljstvo u svakom slučaju. Pod trećom vrstom pravde se misli na pružanje savjeta, klonjenje svakog vida pronevjere, njeno pridržavanje u svakoj situaciji i klonjenje svega lošeg u bilo kom obliku - verbalnom, praktičnom, javno, tajno itd. Riječ pravda - el-'adl u Kur'anu je spomenuta 28 puta što dovoljno govori koliku važnosti islam daje pravdi.

Pravda u islamu je univerzalna i nema lokalnu, vjersku, nacionalnu ili rasnu dimenziju kakvu je imala i ima kroz cijelu ljudsku historiju. Kur'an na mnogo mjesta imperativno naređuje pravdu što implicira njenu obligatnost na svim segmentima ljudskog života a posebno zakonodavnog i političkog. Allah vam zapovijeda da odgovorne službe onima koji su ih dostojni povjeravate i kada ljudima sudite da pravično sudite. Uistinu je divan Allahov savjet! - A Allah doista sve čuje $i$ vidi. (En-Nisa, 58.) Poslanik, a.s., u mnogim hadisima ukazuje na važnost pravde i pogubnost nepravde. Najdraži čovjek Allahu i najbliži na Sudnjem danu je pravedan vladar, a najmrži i najudaljeniji je nepravedan vladar.“ (Tirmizi i Taberi) „Bojte se dove kome je učinjena nepravda jer između nje i Allaha nema perde." (Buharija i Muslim) „Kada sudite i vladate, sudite i vladajte pravedno.“(Taberani)

Kada se nađu pravda i nevjerstvo u nekoj instituciji, ona će zbog pravde opstati i napredovati, a kada se nađu nepravda i vjera takva institucija će zbog nepravde nestati i doživjeti poniženje i svoj krah. Sve navedeno je Omer b. El-Hattab, r.a., naučio direktno od Poslanika, a.s., čvrsto vjerovao u te ideale i kada mu se pružila prilika da ih u stvarnosti i praktično primjeni nije se ni najmanje dvoumio. Njegova dosljedna primjene principa i načela pravde koji sprečavaju nepravdu imalo je logičnu refleksiju uspostave pravednog društva na svim segmentima države kojom je on vladao. U nastavku studije ćemo elaborirati osnovne preventivne mjere koje je Omer, r.a., primijenio i u potpunosti 
uspostavio pravdu i iskorijenio korupciju u tadašnjoj islamskoj državi. Njih možemo podijeliti na političke i administrativne.

\section{Prvo: Omerove, r.a., političke mjere}

Nakon smrti prvog halife Ebu Bekra, r.a., muslimani su se saglasili da daju prisegu Omeru, r.a., nakon prijedloga i preporuke Ebu Bekra, r.a., neposredno poslije njegove smrti. U toj preporuci između ostalog stajalo je: ,...ja vam namjesto svoje ostavljam Omera b. El-Hattaba pa ga slušajte i pokoravajte mu se...ako bude pravedan prema vama pa to je moje mišljenje i očekivanje od njega, a ako tako ne postupi ja sam vam samo želio dobra jer ja ne znam gajb - nevidljivo. ${ }^{\text {“1 }}$ Ebu Bekr je naredio Osmanu, r.a., da napiše navedenu oporuku, koja je imala samo status prijedloga - savjeta ummetu i upute savjetodavnom vijeću - šuri, jer bez prisege ummeta Omer ne bi mogao postati halifa samo na osnovu Ebu Bekrova prijedloga. ${ }^{2}$ Tek nakon što su muslimani dali prisegu Omeru i saglasili se da im bude vođa on je izabran za halifu muslimana.

Nakon imenovanja, Omer, r.a., se uspeo na minber i između ostalog u svom prvom obraćanju rekao muslimanima: „Allah me je iskušao s vam kao što je i vas iskušao sa mnom. Tako mi Allaha, svaki vaš zahtjev koji dođe do mene lično ću ga ja rješavati i niko drugi, a koji ne mogne stići do mene, imenovat ću kompetentne, snažne i povjerljive da ih riješe. Ako budu dobro radili biću dobar prema njima a ako ne budu sigurno ću ih kazniti....obračunavajte sami sebe prije nego što vas budu drugi obračunavali...ja ću se odnositi prema Allahovoj imovini javnom dobru kao staratelj jetima prema imovini jetima. Ako budem nepotreban neću joj se primicati, a ako budem u potrebi uzet ću samo koliko mi je potrebno i uobičajeno. ${ }^{\text {(3 }}$

Novi halifa je u svom prvom obraćanju jasno definirao principe svoje politike i vladavine jasno ističući kakve će državne službenike postavljati na javne funkcije. Moral, stručnost, odlučnost i

\footnotetext{
1 Numejri, Ibn Šejbe El-Bari, Tarihul-medine, tahkik: Fehim Muhammed Šeltut, Džeddeh, 1399. h. str. 669.

2 El-Umeri, Ekrem Dija, 'Asrul-hilafer-rašide, Rijad: Mektebetul-ubejkan, prvo izdanje, str. 55-56.

${ }^{3}$ Ibn S'ad, Et-Tabekat, 3/208.
} 
kompetentnosti su bili glavni uvjeti koje je morao ispunjavati svako onaj koji je pretendovao da bude postavljen na neku od javnih službi kod Omera, r.a. Putem ovih svojstava Omer se indirektno suprotstavio svim oblicima korupcije posebno one političke i administrativne. Na taj način je imunizirao državu od mita, pronevjere i kapitalizacije opće funkcije za ličnu korist i promidžbu. Pored navedenih uvjeta istakao je još i snagu s namjerom zaštite i očuvanja državnih institucija i općeg interesa od svakog vida lakrdije $\mathrm{i}$ anarhije, te uvođenja potpune transparentnosti daleko od svakog vida manipulacije i obmane. Slab službenik sigurno ne može biti dostojan obnašanja javnih funkcija zbog velike odgovornosti i ogromne važnosti koju one iziskuju. Javne funkcije zahtijevaju posjedovanje posebne snage i moći kako bi oni koji pretenduju na njih mogli bez ikakve dileme, slabosti, odgađanja i dvoumljenja donijeti i provesti velike i važne odluke bez straha ili bojazni od bilo koga. Zato je obaveza da se za javne funkcije predlože ljudi sa snažnim i jakim, one koji su stručni i moralni kako bi bili kompetentni da ponesu odgovornosti i da bez ikakva dvoumljenja uzmu stvari u svoje ruke i obnašaju takve funkcije u koristi općeg dobra a ne ličnog interesa i koristi. Navedene uvjete je Kur'an potvrdio kroz kazivanje o Jusufu, a.s.: I vladar reče: "Dovedite mi ga, uzeću ga u svoju svitu" - i pošto porazgovara s njim, reče mu: "Ti ćeš od danas kod nas utjecajan i pouzdan biti." "Postavi me" - reče - "da vodim brigu o stovarištima u zemlji, ja sam zaista čuvaran i znan." (Jusuf, 54 - 55)

Omer, r.a, je bio svjestan velike odgovornosti koju je preuzeo na sebe. Od Alije, r.a., se prenosi da je rekao: „Vidio sam Omera na devi kako žuri pa sam ga upitao: „Vođo pravovjernih, gdje žurišs? “ Deva od zekjata je pobjegla pa je tražim“, rekao je. Ponizit ćeš na taj način one koji će doći poslije tebe, rekao sam. „Oče Hasanov, ne kori me, tako mi Onoga koji je poslao Muhammeda s poslanstvom, kada bi koza na obali Eufrata posrnula, na Sudnjem danu bi Omer zbog nje bio pitan. ${ }^{\text {" }}$ Isto tako Omer, r.a., je često svoje službenike upozoravao i skretao im pažnju na emanet koji su preuzeli govoreći im: „Ne zatvarajte vrata pred

\footnotetext{
4 Jusuf b. Hasan b. Abdulhadi El-Muberred, Mahdus-savabi fi fedaili emirilmu'minine Omer b. El-Hattab, tahkik: Abdulaziz b. Muhammed b. Abdulmuhsin, ElDžami'atul-islamijjeh, Medina, 2000, 2/261.
} 
narodom pa da jači potčinjavaju slabe. ${ }^{* 5}$ Ova oporuka aludira na Omerovu pronicljivost $\mathrm{i}$ dalekovidnost $\mathrm{u}$ političkim $\mathrm{i}$ administrativnim pitanjima i otkriva njegov program i sistem protiv mita i korupcije. Ona u sebi involvira najvažnije principe i pravila savršene strategije na svim segmentima vladavine: vjerskom, političkom, vojnom, ekonomskom i društvenom.

Govoreći u svom prvom obraćanju o javnoj imovini postavio je veoma bitno ustavno i zakonsko načelo radi zaštite i očuvanja javne imovine od onih koji su na vlasti gdje je podvukao muslimanima da će se on odnositi prema toj imovini kao staratelj ili tutor prema imovini jetima. Dakle, biće njen čuvar a ne onaj koji će je potkradali, krasti, otimati, manipulirati s njom, niti onaj koji će iznevjeriti preuzeti emanet. Nakon toga, bio je dosljedan svog govora pa je sebi postavio mnogobrojne preventivne mjere kako ne bi uzimao društvenu imovinu.

Najvažnija preventivna mjera koju je u tom smislu poduzeo jeste skromnost i siromaštvo. Kada halifu zadesi siromaštvo i neimaština tek tada ima pravo da uzme iz državne blagajne ali i tada umjereno i uobičajeno bez rasipanja, raskoši i pretjerivanja ili iskorištavanja takvog stanje da se domogne bogatstva na račun imovine muslimana. Zabranio je sebi i onima koji obnašaju javne funkcije da se bave trgovinom kako bi zaštitio ugled države i spriječio iskorištavanje javnih funkcija za ličnu korist. S toga je rekao da se halifa neće primicati društvenoj imovini ako bude imao dovoljno svoje imovine, a ako ne bude, onda će odrediti uobičajena primanja sebi i ostalima, zbog toga što im funkcije ne dozvoljavaju bavljenje drugim poslovima, kako bi se u potpunosti mogli posvetiti općem interesu muslimana. ${ }^{6}$

Drugi halifa je postavio najvažnija ustavna i administrativna državna pravila s kojima je sebe obavezao da ih slijedi pri upravljanju islamskom državom. Osjetio je da ga se ljudi boje zbog njegove strogosti. Stoga ih je nakon dva dana od preuzimanja vlasti okupio i pojasnio im svoju politiku koju će slijediti pri upravljanju državom radi zaštite vjere i interesa muslimana rekavši: „Obaviješten sam da me se ljudi boje zbog moje strogosti i da se plaše moje osornosti tvrdeći da je

\footnotetext{
${ }^{5}$ Ibn S'ad, Et-Tabekat, 3/339.

${ }^{6}$ Akkad, Abbas Mahmud, 'Abkarijetu Omer, Kairo, Daru nehda, prvo izdanje, 1998. str. 5 .
} 
Omer bio grub prema njima za vrijeme Poslanika, a.s., da je takav bio i za vrijeme Ebu Bekrove vladavine a tek kakav će biti sada kada je vlast prešla u njegove ruke?“ Zatim je rekao: „O ljudi, ja sam preuzeo vođstvo nad vama pa znajte da je ta strogost splasnula, ali će i dalje ostati još žešća prema onima koji čine nepravdu i nasilje muslimanima, a prema onima koji su pravedni, uljudni i dobronamjerni ću biti mekši nego što su oni jedni prema drugima. Neću dozvoliti da bilo ko nekom čini nepravdu... Moje obaveze prema vama su: da od vas ništa bespravno ne uzimam, da ono što s pravom uzmem trošim samo $u$ legalne svrhe...da vam prihode povećam i zaštitim granice vaše države, a kada odete u borbu ja ću biti staratelj vaših porodica sve dok se ne vratite " 7

U ovom obraćanju je jasno definirao sljedeće principe svoje politike:

- da će njegova strogost i odlučnost biti samo prema nepravednicima, nasilnicima i onima koji na bilo koji način ne poštuju prava muslimana, - da neće dozvoliti nikome ma ko on bio da učini nasilje i nepravdu prema bilo kome,

- da neće nametati građanima nepravedne poreze kako bi se na taj način domogao njihove imovine,

- da će biti čuvar javne imovine i da će na taj način spriječiti imovinsku i administrativnu korupciju u državi te da će je trošiti samo na legalan način kako je to definirao vrhovni Zakonodavac,

- da će raditi na povećanju standarda života građana sukladno prilikama i mogućnostima,

- da će raditi na smanjenja siromaštva i nezaposlenosti koji su glavni uzroci korupcije u svakom društvu.

- da je država obavezna socijalno zbrinuti sve muslimana i nemuslimana - građane islamske države što do tada nije bilo poznato $\mathrm{u}$ historiji. ${ }^{8}$

- da će zaštiti granice islamske države i

\footnotetext{
${ }^{7}$ Salabi, Faslul-hitabi fi sireti emiril-mu'minine ibnil-Hattab, str. 102-103.

8 Taha, Husejn, Ěs-Šejhani (Es-Siddik Ebu Bekr vel-Faruk Omer), Kairo, Derulme'arif, treće izdanje, 1966., str. 188.
} 
- da je država obavezna brinuti o porodicama vojnika koji odu u borbu sve dok se ne vrate. Prema onima koji su bili u Medini bio je kao njihov sluga a prema onima koji su bila zvan Medine brinuo se i pitao o njihovom stanju.

Isto tako, u svojoj političkoj strategiji uvrstio je i realizaciju projekata $i$ programa prethodnog halife. $\mathrm{S}$ toga je poslao vojsku u Irak pod vođstvom Ebu Ubejde i Musennea b. Harisa, r.a., i to u zoru iste noći u kojoj je umro Ebu Bekr, r.a., jer je Ebu Bekr to imao u planu. Na taj način je potvrdio veličanstven princip institucionalnog kontinuiteta koji se ne smije prekidati pa je stoga odlučio da nastavi tamo gdje je stao njegov prethodnik i realizuje strategiju koju je on zacrtao nastavljajući islamska osvajanja čvrsto vjerujući da je ta strategija potpuno ispravna i da je treba slijediti i nastaviti njenu realizaciju. ${ }^{9}$

$\mathrm{Na}$ takav način se treba odnositi svaki lider prema svom prethodniku; da ono što je ispravno radio nastavi razvijati i usavršavati, a neispravno popraviti i zanemariti jer se samo na taj način i jedino može učiniti istinska reforma.

\section{Drugo: Omerove, r.a., administrativne mjere}

Omer, r.a., je za vrijeme svoje relativno kratke vladavine islamskom državom donio i primijenio mnogobrojna načela i zakonodavstva, do kojih je savremeni svijet u skorije vrijeme došao i primijenio ih, i na taj način prevenirao i zaštitio islamsku državu od tiranije i nepravde kao glavnih izvora nereda i korupcije svih vrsta a naročito administrativne. U nastavku studije ćemo se ukratko osvrnuti na neka od tih preventivnih mjera. Najpoznatije su:

1- Princip nepodmitljivosti, transparentnosti i odgovornosti

Omer, r.a., je primjenjivao ovaj princip krajnje odgovorno fokusirajući se na svijest i ubjeđenje da je vođenje ummeta odgovornost i emanet za koje će se odgovarati pred Allahom na Sudnjem danu pa je stoga svoju funkciju doživljavao kao najveću obavezu i odgovornost koju mora izvrši na najbolji način. U tom smislu je nastojao da se distancira od

${ }^{9}$ Muhammed Rida, Umer b. El-Hattab sanil-hulefair-rašidin, str. 79. 
svega što bi na bilo koji način moglo devalvirati tu odgovornost i emanet.

Isto tako je bio potpuno transparentan u svojoj politici koju je stalno jasno objašnjavo i isticao u svim svojim javnim nastupima. Kada bi htio da zabrani ljudima nešto, okupio bi prvo svoju porodicu i rekao bi im: „Zabranio sam ljudima to i to, pa će oni gledati u vas kao što ptica gleda na meso, pa ako to budete radili i oni će to raditi, a ako ne budete to radili ni oni ga neće raditi. Tako mi Allaha, ako neko od vas nešto uradi od onoga što sam zabranio duplo ću ga kazniti. “10

Ovom izjavom je Omer, r.a., naslovljena tri principa riješio u dvije rečenice, a danas se o njima pišu mnogobrojne studije, provode istraživanja, održavaju naučne konferencija itd., ali bez ikakvog ili vrlo malog napretka.

Nepotizam je tako lahko rješiv ukoliko se shvati smisao, odgovornost $i$ teret funkcije koja se preuzima. Omer je jasno rekao i upozorio svoje najbliže da se neće libiti da ih kazni duplo više nego ostale ukoliko nešto urade što je zabranio, ili na bilo koji način kapitaliziraju javnu funkciju koju obavljaju u svoju korist. Omer je bio potpuno svjestan da ukoliko se vladar i njegovi najbliži budu pridržavala zakona, onda će ih se bez sumnje i podređeni pridržavati, u suprotnom neće jer će im postupci nadređenih biti alibi da ih krše i izbjegavaju njihovu primjenu. Koliko je Omer po tom pitanju bio strog i oprezan najbolje govori sljedeći slučaj. Ebu Musa El-Eš'ari pripovjeda da je jedne prilike poklonio Omerovoj ženi komad neke prostirke pa ju je Omer upitao odakle joj. Kada mu je rekla da joj ju je poklonio Ebu Musa El-Eš'ari, Omer ju je uzeo i udario je s njom po glavi rekavši: ,Dovedite mi Ebu Musa da mu ja pokažem!“ Kada su ga pozvali zamolio ga je da ne žuri sa presudom. Omer ga je upitao šta ga je navelo pa da poklanja njegovoj ženi to šta je poklonio, pa ga je udario s njom po glavi i rekao da uzme tu prostirku da oni nemaju potrebe za njom. ${ }^{11}$

Navedeni slučaj jasno pokazuje kako je Omer, odbijao primanje bilo kakvih poklona za sebe ili za bilo koga od njegove porodice pa makar

${ }^{10}$ Es-Sa'idi, Abdulmute'al, Es-Sijasetul-islamijjetu fi 'ahdil-hulefair-rašidin, Kairo, Darul-fikril-arabi, prvo izdanje: 1962., str. 119-120.

${ }^{11}$ Tantavi, Ali, Ahbaru Abdullahi b. Omer, Bejrut: El-Mektebul-islami, osmo izdanje, 1983., str. 291. 
se radilo i o poklonima od najpoznatijih ashaba. Primjena ovog principa je bez sumnja najbolja preventivna mjere da se spriječi takva praksa kod ostalih državnih službenika jer bi to u krajnjoj konsekvenci imalo za posljedicu korupciju i mito.

Drugi primjer koji potvrđuje ovu Omerovu dalekovidnost je dolazak jedne pošte od bizantijskog cara. Nakon njena dolaska Omerova žena, Umm Kulsum, Alina kćerka, pozajmila je jedan dinar i kupila neki miris i stavila ga u jednu prikladnu ambalažu, te poslala ženi bizantijskog cara. Na njen poklon kraljica je uzvratila i poslala Omerovoj ženi vrijednu ogrlicu. Kada je pošta došla do Omera, uzeo je tu ogrlicu, prodao je i pare stavio u državnu kasu a svojoj ženi vratio dinar rekavši da je na taj način u svoju korist kapitalizirala njegovu funkciju pa dobila poklon i iskoristila državnu poštu pa stoga sva dobit mora ići u državnu blagajnu. Primanje poklona od podanika ili druge države je u stvari korupcija i mito obuvena u odjeću poklona jer se putem takvih poklona želi postići neka privilegija, benefit i korist na uštrb općeg interesa ili tuđih prava.

Omer je posebno bio oprezan i neupitno je štitio javno dobro od strane njegovih najbližih. Njegov sin Abdullah b. Omer je rekao: „Kupio sma neke deve i dao ih na državnu ispašu. Kada su se ugojile doveo sam ih da se prodaju. Kada je Omer došao na pijacu i vidio te ugojene deve upitao je čije su? Kada mu je rečeno da su to deve njegova sina počeo se čuditi i govoriti: O Abdullahu. O Abdullahu..vidi ti vidi...deve sina vođe pravovjernih!?“'Kada me je upitao odakle mi te deve, rekao sam mu da sam ih kupio i držao na državnoj paši želeći samo ono što žele i svi muslimani. Rekao je: „Na taj način si rekao čuvajte deve sina vođe pravovjernih! Napajajte deve sina vođe pravovjernih! Abdullahu, uzmi svoju glavnicu koju si uložio u njih a ostalo vrati u državnu kasu muslimana. “12

Ovaj primjer jasno odslikava i potvrđuje koliko je Omer, r.a., bio oprezan i odlučan po pitanju kapitalizacije njegova položaja kada su bile u pitanju i trgovinske i robne transakcije i zarada s toga je oduzeo od sina deve. To je uradio zbog toga što su one imale poseban tretman na državnoj ispaši jer su bile u vlasništvu halifina sina. Zbog toga je

${ }^{12}$ Ebu Bekir, Bejheki, Es-Sunenul-kubra, Bejrut, Darul-kutubil-'ilmijje, treće izdanje, $6 / 234$. 
odlučno zahtjevao od svog sina da uzme svoju glavnicu a zaradu vrati u državni budžet.

Ovo je najbolji primjer primjene principa transparentnosti, nepodmitljivosti i odgovornosti protiv nepotizma i korupcije. Navodi se da je jednom kada mu je došla neka imovina i kada je za nju saznala njegova kćerka Hafsa rekla mu je: ,,Vođo pravovjernih. Gdje je pravo tvoje rodbine u tom imetku, jer je Allah naredio da se rodbina pazi?“‘ Odgovorio joj je: „Kćeri moja, pravo moje rodbine je u mom imetku, a ovo je imovina muslimana. Obmanjuješ svoga oca i podstičeš svoju rodbinu protiv mene. “13

Jedne prilike je pred Amrom b. Asom spomenut Omer pa ga se s poštovanjem sjetio i rekao: „Nisam vidio da se iko više bojao Allaha od njega a niti je bilo pravednijeg od njega. Nije mario kazniti svakog onog ko je god zaslužio da se kazni pa makar to bilo njegovo dijete, otac...te je spomenuo i ispričao događaj sa Abdurahmanom, Omerovim sinom, kada je nad njim izvršio kaznu zbog toga što se napio. “"

2- Principi i pravila koje je Omer postavio pri izboru i imenovanju službenika

Omer je pri imenovanju službenika slijedio strategiju Poslanika, a.s., i Ebu Bekra, r.a., koja se prije svega temeljila na kompetentnosti onih koji su najsposobniji da služe ummetu i općem interesu. Tako je birao samo one koji su bili dostojni svoje funkcije, odlučni, učeni i autoritativni u narodu. Omer, r.a. bi u tom smislu govorio: „Želim čovjeka koji kada je u narodu a nije njihov lider izgleda kao da im je lider. A kada je njihov lider izgleda među njima kao jedan od njih.“

Kada bi imenovao nekoga na položaj ne bi ga ostavio da radi šta hoće, nego bi mu odredio principe i opća pravila koja bi trebao primjenjivati pri vršenju svoje funkcije i na osnovu njih bi ga obračunavao, kontrolisao i pratio. Obično bi ta pravila bila sadržana u dekretu o imenovanju koji bi se obično pročitao pred muhadžirima i ensarijama, jer je on sebe smatrao odgovornim za sve greške koje bi počinili njegovi službenici. Ponekad bi kada bi htjeo da imenuje nekog na neki položaj

\footnotetext{
${ }^{13}$ Ibn S'ad, Tabekat, 3/278.

${ }^{14}$ Ibn Kesir, Musned emiril-mu'minine Ebi Hafs Omer b. El-Hattab, Darul-vefa, prvo izdanje, Mensure,1991., 2/18.
} 
naveo i uvjete koje mora ispuniti i onda bi prepustio prisutnima da između sebe izaberu takvog. Ti uvjeti su bili:

a - da onaj koji se imenuje ne traži niti želi funkciju i položaj. Omer, r.a., je tražio za odgovorne funkcije one koji su bili skromni - zahidi po pitanju ovoga svijeta - one koji ga odbijaju i ne žele. Kategorički je odbijao imenovati svakog onog koji traži i žudi za položajem slijedeći pri tome upute Poslanika, a.s., jer je smatrao da takav nije kompetentan da iskreno i odgovorno obavlja funkciju koju preuzme. U tom smislu se od njega prenosi da je rekao: „Ko žudi za položajem neće biti pravedan na njemu. “" ${ }^{15}$ Traženje položaja je potvrda da se on obično traži za lični interes pa ta njegova pohlepa za položajem skrnavi njegovu kompetentnost.

b- da onaj koji se imenuje bude jak - odlučan i povjerljiv. Omer, r.a., je na položaje postavljao ljude kod kojih je nalazi ova svojstva i pored toga što je na raspolaganju imao one koji su bili pobožniji i znaniji od njih. $^{16}$

Prednost je davao jačim nad jakim pa je tako smijenio Šerhabila b. Haseneta i umjesto njega imenovao Muaviju pa mu je Šerhabil rekao: „Jesi li me to iz mržnje smijenio vođo pravovjerni?!“ Rekao mu je: „Ne, ja te volim ali želim jačeg čovjeka. “17

Ovaj princip Omer je primjenjivao i na sebi pa je rekao: „Da znam da ima iko jači - sposobniji od mene za ovaj položaju, smrt bi mi draža bila od tog položaja. “18

c- da aplikant bude iskusan. Zbog toga je Omer, r.a., postavljao i ostavljao iskusnije ljude na položajima a zanemarivao i smjenjivalo one koji su bili bolji od njih po pobožnosti, moralu, bogobojaznosti, jer nije nužno da se kod nekoga nađe zajedno iskustvo i pobožnost. Ovo pravilo koje je Omer postavio i danas se primjenjuje u najnaprednijim državama.

\footnotetext{
15 Abdusselam b. Muhsin, Dirasetun-nakdijetun fil-mervijatil-varide fi šahsijjeti Omere b. El-Hattab ve sijasetuhul-idarrijjeh, El-Džami'atul-islamijjeh, El-Medinetulmunevvereh, prvo izdanje, 2002., str. 633.

16 Tantavi, Ahbaru Abdullah b. Omer, str. 128.

${ }^{17}$ Ibn Ebi Šejbe, El-Musannef, 2/798, Taberi, Tarih, 2/490.

${ }^{18}$ Ibn S'ad, Tabekat, 3/275., Ibn El-Dževzi, Menakib, str. 58.
} 
d- da onaj koji se postavlja na položaj bude milostiv i suosjećajan. Omer je imenovao na položaje samo one koji su imali senzibilitet prem narodu. One koji su bili tvrdih srca i koji nisu imali milosti nije postavljao na bilo kakvu funkciju. Smatrao je da je milost bitno i esencijalno svojstvo koje mora nadređeni posjedovati jer će se bolje odnositi prema podređenima, više će se međusobno voljeti i uvažavati i slobodnije će od njega tražiti svoje potrebe i ukazivati na nepravdu.

Prenosi se da je jednom na neki položaj postavio nekog čovjeka iz plemena Esed. Nakon toga je došao kod Omera da ga poselami, pa je tad Omeru dovedeno jedno od njegove djece kojeg je Omer poljubio. Čovjek je tada rekao: „Zar ti djecu ljubiš vođo pravovjernih?! Tako mi Allaha ja nikada dijete nisam poljubio.“ Omer je tada rekao: „Tako mi Allaha ti si onda još nemilosrdniji prema svojim podanicima. Više mi nikad nećeš bilo kakvu funkciju obavljati““, pa ga je odmah i smijenio. ${ }^{19}$

3- Zabrana odgovornim - liderima da se bave trgovinom ili da sklapaju trgovačke transakcije

Omer, r.a. je strogo zabranio svojim namjesnicima i službenicima da se bave trgovinom i da sklapaju poslovne ugovore bez obzira da li bili kupci u njima ili prodavci. Jedne prilike na svom službeniku po imenu Haris b. K'ab b. Vehb je vidio raskoš - bogatstvo pa ga je upitao o njegovu porijeklu. Odgovorio mu je da je to stekao trgovinom pa mu je Omer rekao: „Tako mi Allaha mi vas nismo poslali da trgujete pa je uzeo od njega svo bogatstvo koje je stekao trgovinom. ${ }^{\text {‘20 }}$

\section{4- Zabrana nepotizma}

Omer, r.a., je strogo pazio da nikoga od svoje familije ne postavi na neki položaj i pored toga što su neki bili kompetentni i bili od onih koji su među prvim primili islam. U tom smislu bi govorio: „Ko postavi nekoga na položaj zbog pristrasnosti ili rodbinske veze iznevjerio je Allaha i Njegovog Poslanika.“21 Na taj način je u korijenu sasjekao sve oblike korupcije.

\footnotetext{
${ }^{19}$ Bejheki, Es-Sunenul-kubra, 3/367.

20 Šelebi, Es-Sijasetu fil-fikril-islami, str. 119.

${ }^{21}$ Salabi, Faslul-hitabi fi siretil-emiril-mu'minine b. El-Hattab, str. 281.
} 
5- Imenovanje namjesnika je moralo proći kroz cijeli jedan proces mjera predostrožnosti

Omer, r.a., bi predlagao nekoga na položaj tek nakon što bi proveo niz mjera predostrožnosti poput tajnog i javnog raspitivanja, zatim traženja mišljenja od savjetodavnog vijeća o njemu itd. Službenika bi imenovao tek nakon što bi njegove osobine bile detaljno preisipitane. Kandidatima bi sam postavljao tajne i javne ispite kako bi se uvjerio u njihovu sposobnost i moralnost. Njegovi službenici su bili primjeri bogobojaznosti, skromnosti, dobra, iskrenosti pri obavljanju svojih dužnosti.

6- Provjera imovinskog stanja pri imenovanju službenika

Radi sprečavanja mita i korupcije i kapitaliziranja javne funkcije Omer je provjeravao imovinsko stanje svojih namještenika prije njihova imenovanja. U tom smislu Akkad je rekao: „Omer b. El-Hattab je provjeravao imovinu svojih službenika prije njihove inauguracije preuzimanja funkcije kako bi ih poslije toga mogao kontrolisati da li su poslije preuzimanja položaja kapitalizirali svoj položaj i povećali svoju imovinu. Ukoliko bi neko od njih povećanje svoje imovine obrazložio sa bavljenjem trgovinom ne bi mu to prihvatio kao opravdanje jer bi im govorio da ih nije poslao kao trgovce nego narodne sluge. ${ }^{622}$

Prenosi se da je Omer uzurpirao Amr b. Asu pola njegove imovine jer toliku imovinu nije posjedovao kada je preuzeo položaj. ${ }^{23}$ Omer je uobičajio da zatraži od svojih službenika da predaju pri preuzimanju funkcije svoje imovinske kartone ili prikažu privatnu imovinu koju su posjedovali. Ukoliko bi se poslije preuzimanja funkcije obogatili oduzimao bi im pola ili svu imovinu. ${ }^{24}$

Omer je prema njegovim službenicima bio najstrožiji od svih pravednih halifa pa im je oduzimao pola imovinu ukoliko bi se ona nelegalno povećala kao što bi ih i kažnjavao ukoliko bi zavladao nered ili se desile neke financijske malverzacije.

7- Politika otvorenih vrata

\footnotetext{
${ }^{22}$ Akkad, 'Abkarijetu Omer, str. 96.

${ }^{23}$ Belazuri, Futuhul-buldan, str. 220- 221.

${ }^{24}$ Harekat, Es-Sijasetu vel-mudžteme'u fi asrir-rašidin, str. 239.
} 
Omer je primjenjivao politiku otvorenih vrata koju je nakon toga generalizirao i na sve svoje službenike u njihovom odnosu prema podanicima, te im strogo zabranio da postavljaju bilo kakve barijere između njih i naroda. Ko bi se oglušio o ovaj princip Omer bi ga smjenjivao.

Prenosi se da su se stanovnici Kufe jednom požalili Omeru na S'ada b. Ebi Vekkasa zbog njegova zatvaranja vrata na dvorcu i distanciranja od njih i njihovih potreba. Omer je nakon toga poslao Muhammeda $b$. Meslemu, administrativnog inspektora, u Kufu i naredio mu da zapali vrata S'adova dvorca što je on i učinio. ${ }^{25}$

Prema tome, Omer je strogo zabranjivao svojim službenicima da se izoluju od naroda jer je smatrao da takvo ponašanje implicira distanciranje od naroda i njegovih problema, te da na taj način neće biti upoznati sa njegovim stanjem na i kraju dovesti do širenja svih vrsta korupcije, nasilja, siromaštva i postepenog rušenje društvenog sistema zbog pokvarenosti vladara i njegova distanciranja od naroda. Stoga je Omer, savjetovao svakog svog namjesnika govoreći mu: „Otvori im vrata, lično rješavaj njihove probleme jer ti si samo jedan od njih, osim što te je Allah samo zadužio sa težim teretom.“26

8- Kažnjavanje službenika koji prekrše zakone

Od metoda koje je Omer, r.a., koristio pri sprečavanju korupcije je i automatsko kažnjavanje svojih službenika koji se ne bi pridržavali svega onoga što im nalaže funkcija koju su obnašali. Bilježi IbnulDževzi da je Omer, r.a., jedne prilike sjedio sa svojim drugovima pa je pored njih prošao neki čovjek i rekao: „Boj se vatre Omere!“ „Zašto?“ upitao ga je. Čovjek je rekao: „Postaviš službenika na položaj i nakon toga ga ne kontrolišeš da li se pridržava uvjeta koje si mu zacrtao ili ne, pa on zbog toga ne radi ono što si mu naredio a radi ono što si mu zabranio“, misleći na čovjeka kojeg je bio postavio i uslovio mu određene uvjete. Čuvši to, Omer je odmah poslao dvojicu ljudi rekavši im da se raspitaju o njemu. Kada su utvrdili da je čovjek istinu rekao došli su na vrata tog službeniku i zatražili dozvolu da uđu kod njega. Međutim, nije im dozvolio. Rekli su mu da izađe pred njih ili će mu

\footnotetext{
${ }^{25}$ Belazuri, Futuhul-buldan, str. 277., Taberi, Tarih, 2/480-481.

${ }^{26}$ Akkad, 'Abkarijetu Omer, str. 94.
} 
zapaliti vrata. Uzeli su ga i doveli Omeru. Omer ga je upitao: „Teško tebi, ko si ti?!“ Rekao je da je njegov namjesnik u Egiptu, a bio je beduin. Rekao mu je: „Postavio sam te na položaj i rekao ti kako treba da radiš a ti si se o sve to oglušio. Tako mi Allaha kazniću te najvećom kaznom.... 27

9- Princip pravde i jednakopravnosti pred zakonom

Princip pravde $\mathrm{i}$ jednakosti pred zakonom je istinski primjenjivan $\mathrm{u}$ vrijeme Poslanika, a.s., Ebu Bekra, r.a., i nije bilo nikakve rasne, nacionalne ili bilo koje druge diskriminacije. Historija nam bilježi da su pred sudom u to vrijeme znali se naći na istom mjestu obični građanin i najveći državni službenik pa čak i sam halifa.

Kada je Omer došao na mjesto halife nastavio je sa primjenom ovog principa ali još rigoroznije i odlučnije. Nije se libio da po svaku cijenu realizuje istinu, uspostaviti pravdu među ljudima pa je na taj način s pravdom i pravičnosti osnažio i zaštitio državu od svakog vida nepravde, nasilja, tiranije i korupcije.

Ibnul-Dževzi bilježi da je Omerov namjesnik Ebu Musa El-Eš'ari dao nekom čovjeku samo dio njegova udjela - prava pa je on to odbio tražeći cijeli iznos zbog čega ga je Ebu Musa kaznio sa dvadeset bičeva i ošišao ga. Čovjek je potom sakupio svoju kosu i uputio se Omeru. Došavši kod njega ispričao mu je sve šta mu se desilo. Omer je potom napisao Ebi Musau sljedeće: „Selam. Neki čovjek me je obavijestio o tome i tome. Ako si to uradio pred ljudima, naređujem ti da ti on vrati istom mjerom također pred ljudima. A ako si mu to uradio nasamo, onda $\mathrm{i}$ njemu omogući da i on to tebi uradi nasamo." Kada se čovjek vratio, narod ga je počeo moliti da mu oprosti. Međutim, zakleo se Allahom da ga neće prepustiti nikome od njih. Kada je Ebu Musa sjeo da mu čovjek vrati istom mjerom, čovjek je podigao glavu prema nebesima i rekao: „Bože, oprostio sam mu. “28

Omerova praksa je bila da svaku tužbu istraži i ispita, te da kazni počinioce bez obzira o kome se radilo - najvećem državnom službeniku ili običnom građanu. Svako bi bio pravedno kažnjen sukladno zlodjelu

\footnotetext{
${ }^{27}$ Ibnu-Dževzi, Menakibu emiril-mu'minine Omer b. El-Hattaba, str. 115- 116.

${ }^{28}$ Ibnul-Dževzi, Menakibu emiril-mu'minine Omer b. El-Hattaba, str. 93-94.
} 
kojeg je počinio. Ko bi nekog udario i bio bi kažnjen istom mjerom, ko bi nekome nasilje učinio kažnjen bi bio još više itd.

Ponekad bi namjesnik bio kažnjavan i zbog prestupa njegove djece ili rodbine ukoliko bi se utvrdilo da su nekome nepravdu učinili iskoristivši položaj njihova rođaka namjesnika ako ih on ih u tome nije spriječio. $^{29}$ Takav je bio slučaj sa namjesnikom Egipta Amrom b. ElAsom, koji nije spriječio svog sina da ponizi Kopta pa ga je Omer zbog toga kaznio nakon što ga je Kopt o tome obavijestio.

10- Princip smjenjivanja namjesnika i službenika zbog određenih dilema i sumnji

Omer je bio veoma strog prema svojim namjesnicima i službenicima. Stoga ih je stalno kontrolisao i nadgledao. Kad god bi mu o njima došlo nešto što bi kod njega izazvalo neku sumnju i dilemu odmah bi poslao nekoga ko bi mu to ispitao i provjerio kako bi mogao pravovremeno reagovati i djelovati. Tako je Omer razriješio S'ad b. El-Vekkasa zbog žalbe koju su protiv njega podnijeli neki Iračani optužujući ga za nepravdu u vlasti tvrdeći da ne dijeli i ne sudi po pravdi a niti da ide $u$ džihad pa ga je zbog toga Omer smijenio. ${ }^{30}$

\section{1- Osnivanje direkcije za kontrolu i nadzor}

Omer je prvi u islamu osnovao sistem kontrole i nadzora koji je poslije njega prihvaćen tako da nije bilo nijedne islamske vlasti koja nije imala ovu direkciju. Na taj način je imao uvid i znanje o svakom svom službeniku ma gdje bio. Svaki dan su mu stizali izvještaji o namjesnicima i službenicima što se vidi iz njegovih pisama koja im je slao. ${ }^{31}$

Omer putem navedene direkcije nije kontrolisao i nadzirao samo one koji obavljaju visoke državne funkcije, nego sve službenike jer se bojao da ne dođe do kapitalizacije položaja za lične interese od bilo kojeg službenika. Pri realizaciji ovog principa koristio je različite metode i sredstva poput nadzornika, inspektora itd., tako da se svaki službenik

\footnotetext{
${ }^{29}$ Akkad, Abkarijjetu Omer, str. 97 - 98.

${ }^{30}$ Akkad, Abkarijjetu Omer, str. 97 - 98.

${ }^{31}$ Kasimi, Nizamul-hukmi fiš-šeri'ati vet-tarihil-islami, str. 506.. Džahiz, Et-Tadžu fi ahlakil-muluki, Kairo, El-Matbe'atul-emirijjeti, 1914., str. 165- 166.
} 
bojao i svojih najbližih da njegove prijestupe ne proslijedi i o njima obavijesti Omera, r.a.

Često je nekim službenicima postavljao posebne nadzornike čija je zadaća bila prikupljanje tužbi i žalbi upućenih protiv njega koje bi potom on provjeravao i na taj način bi dobivao pravu slika o tom službeniku zajedno sa vijestima koje su mu dolazile putem agenata.

Isto tako bi naređivao namjesnicima i službenicima da se vraćaju u svoja namjesništva danju kako bi se vidjelo šta nose u povratku sa sobom, a sve to bi pratili stražari, adglednici i o tome ga obavještavali. ${ }^{32}$

\section{2- Princip nadzornih terenskih posjeta}

Ovaj princip je Omera, r.a., zaokupljao prije njegova kukavičkog ubistva. U tom smislu bi govorio: „Ako poživim, ako Bog da, godinu dana ću posveti obilasku svojih podanike, jer znam da ljudi imaju svojih potreba koje ja trebam riješiti, koje mi moji namjesnici ne prosljeđuju a niti oni mogu doći do mene. S toga ću otići do Šama, Egipta, Bahrejn i ostati u njima po dva mjeseca, potom ću se uputiti prema Kufi i Basru u njima provesti po dva mjeseca Tako mi Allaha ta godina će biti divna.." ${ }^{\text {"33 }}$

Dio navedene strategije Omer je prije njegove ubistva i primijenio posebno u Šamu u koga je išao nekoliko puta, kontrolisao svoje namjesnike, i često puta ih iznenađivao dolazeći im nenajavljeno. ${ }^{34}$

Iz navedenih primjera se jasno vidi da je Omer, r.a., bio strog prema svojim namjesnicima i službenicima po pitanju kršenja istine, ljudskih prava $\mathrm{i}$ općeg interesa. $\mathrm{Na}$ taj način je preventivno djelovao na putu sprječavanja korupcije prije njenog dešavanja i širenja u društvu i zajednici. Takva njegova odlučnost i strategija je porodila lidere koji se sve do dan - danas navode kao primjeri pravde, poštenja, moralnosti i zaštite općih interesa. Omer, r.a., je svojim ličnim primjerom i primjerom svoje porodice i rodbine učinio princip kontrole i nadzora državnih službenika veoma jednostavnim i lahkim. To je najbolje opisao Alija, r.a., kada je rekao svoju poznatu izreku o Omerovom

\footnotetext{
${ }^{32}$ Akkad, 'Abkarijetu Omere, str. 97.

33 Tantavi, Ahbaru Omere ve Abdillahi b. Omere, str. 160.

${ }^{34}$ Umeri, Asrul-hilafetir-rašide, str. 119.
} 
odnosu prema državnoj i javnoj imovine: „Sustegao si se od državne javne imovine pa te je i narod u tome slijedio, a da nisi i narod bi se poveo za tobom. ${ }^{635}$

\section{Zaključna razmatranja}

Studija je dovela do sljedećih rezultata:

- Islam je ekvivalentan terminu savremenog značenja cjelokupnog sistema života jer svojim zakonima i normama uređuje sve segmente ljudskog života pa i društveno - političkog, a ne pojmu religije - širi je od njega i involvira ga.

- Političko - administrativni sistem je bio jasno definiran i primjenjivan za vrijeme četverice pravednih vladara a posebno drugog Omera, r.a.

- Korupcija je društvena bolest stara koliko i čovječanstvo.

- Svaka promjena i reforma kako pojedinca tako i zajednice i društva mora počete iznutra, iz srca tj. promjene svijesti i parametra vrijednosti.

- Najbolja prevencija korupcije je istinska vjera i lični primjer.

- Nepotizam, privilegije i nestručnost su glavni krivci i izvori svih vrsta korupcije, nereda, nepravde i propasti.

- Funkcije je zaduženje, teret i emanet a ne privilegije, benefit i kapitalizacija javne službe za lične interese službenika i njegove porodice i rodbine.

- Najveća korupcija i nered na zemlji koji implicira uništenje i nestanak države i društva je prešućivanje i nesuprostvaljanje podčinjavanju i kapitaliziranju svakog oblika javnog interesa i funkcije ličnom interesu.

- Nema samilosti niti tolerancije ni prema kome ko zloupotrebljava funkciju i putem nje čini nepravdu, krši ljudska prava i nelegalno koristi javnu imovinu.

- Službenici se u islamu ne biraju na osnovu samokandnidature, nego putem javnog mnijenja koje treba da prepozna njihovu sposobnost, poštenje i moral. Svako onaj kome muslimani ne daju legitimitet po islamu nije legalan a niti legitiman predstavnik muslimana.

35 Taberi, Et-Tarih, 4/20.23. 


\section{Literatura}

1. Abdusselam b. Muhsin, Dirasetun nakdijetun fil-mervijatil-varide fi šahsijjeti Omere b. El-Hattab ve sijasetuhul-idarrijjeh, El-Džami'atulislamijjeh, El-Medinetul-munevvereh, prvo izdanje.

2. Akkad, Abbas Mahmud, 'Abkarijetu Omer, Kairo, Daru nehda, prvo izdanje, 1998.

3. Belazuri, Ahmed b. Jahja, Futuhul-buldan, Daru mektebetil-hilal, Bejrut, 1988.

4. Bejheki, Ebu Bekir, Es-Sunenul-kubra, Bejrut, Darul-kutubil-'ilmijje, treće izdanje.

5. Džahiz, Et-Tadžu fi ahlakil-muluki, El-Matbe'atul-emirijjeti, Kairo.

6. Ibnu-Dževzi, Menakibu emiril-mu'minine Omer b. El-Hattaba, Daru Ibn Haldun, Aleksandrija, bez godine izdanja.

7. Ibn Ebi Šejbe, El-Musannef, prvo izdanje, 1409., Mektebetur-rušd, Rijad

8. Jusuf b. Hasan b. Abdulhadi El-Muberred, Mahdus-savabi fi fedaili emiril-mu'minine Omer, prvo izdanje, 'Imadetul-bahsil-'ilmijji bildžami'atil-islamijjeti bil-medinetin-nebevijjeh.

9. Kasimi, Nizamul-hukmi fiš-šeri'atil vet-tarihil-islami, Kitabul- hajatiddusturijje.

10. Harekat, Ibrahim, Es-Sijasetu vel-mudžteme'u fi asrir-rašidin, ElEhlijjetu lin-nešri vet-tevzi', Bejrut, 1985.

11. Numejri, Ibn Šejbe El-Bari, Tarihul-medine, tahkik: Fehim Muhammed Šeltut, Džeddeh.

12. b. El-Hattab, tahkik: Abdulaziz b. Muhammed b. Abdulmuhsin, ElDžami'atul-islamijjeti, Medina.

13. Rida, Muhammed, Umer b. El-Hattab sanil-hulefair-rašidin, prvo izdanje, Darul-kutubil-ilmijje, Bejrut, 1996.

14. Salabi, Ali Muhammed, Faslul-hitabi fi sireti emiril-mu'minine ibnilHattab, prvo izdanje, Mektbetus-sahabe, Šarikah.

15. Es-Sa'idi, Abdulmute'al, Es-Sijasetul-islamijjetu fi 'ahdil-hulefairrašidin, Kairo, Darul-fikril-arabi, prvo izdanje.

16. Ibn S'ad, Et-Tabekatul- kubra, Mektebetul- hanki, Kairo, 2002.

17. Šelebi, Ahmed, Es-Sijasetu fil-fikril-islami, sedmo izdanje, Kairo, Mektebtun-nehdatil-misrije.

18. Taberi, Tarihur-rusuli vel-muluki, drugo izdanje, Darul-me'arif, Egipat. 
19. Taha, Husejn, Eš-Šejhani (Es-Siddik Ebu Bekr vel-Faruk Omer), Kairo, Derul-me'arif, treće izdanje.

20. Tantavi, Ali, Ahbaru Abdullahi b. Omer, Bejrut: El-Mektebul-islami, osmo izdanje

21. El-Umeri, Ekrem Dija, Asrul-hilafer-rašide, Rijad: Mektebetulubejkan, prvo izdanje bez godine izdanje. 


\section{Sulejman Topoljak, PhD \\ University of Bihac \\ Islamic pedagogical faculty \\ sulejman.topoljak@hotmail.com}

Original scientific article

\section{PREVENTIVE MEASURES AGAINST CORRUPTION AND BRIBE IN POLITICS AND SERVING AS PUBLIC FUNCTIONS IN THE PHILOSOPHY}

\section{OF OMER B. EL-HATTAB}

\section{ABSTRACT}

The problem of corruption in power and serving in public functions is as old as human society and civilization. Every society has in some way experienced the consequences of this wicked social disease because it could not be fully immunized and protected.Corruption represents a continuous war between good and evil, justice and injustice, objectivity and bias, law, and anarchy. Corruption is a huge social weed - a tree with a very deep root, so it is therefore necessary to have unity and determination among all the positive forces to get rid of it and eradicate it to protect mankind from its deadly fruit.

Preventing corruption is by no means foreign and unknown to Islam, because it is essentially a belief in prevention and protection. The basic aim of Islam is to invite and encourage people to be good and deter and stimulate the removal from evil and leaving sin. All norms and laws of Islam are exclusively and above all preventive means of protection against evil and corruption or the paths leading to good and ways of achieving and realization. Islam is a divine system and a program of prevention and protection in general, and from corruption of all kinds, especially whose application guarantees its prevention and eradication. The intensity of corruption in one society, nation, institution, etc. should be exclusively observed and measured according to the level of adoption, belief and application of Islamic valuesby their superiors and subordinates.

If corruption is intense and widespread in a society, the community, the institution is undoubtedly a belief in Islamic values and their application by the aforementioned scarce or defective and vice versa. This is best corroborated by the current real state of the corrupt world in general, and in particular by 
the Muslim population, which accounts for one-third of the world's corruption of all kinds, according to the available statistical data of those who dealt with this issue. It is evident throughout the world that corruption is increasing day by day, destroying nations and states, and in addition to all preventive measures that take various technical and technological discoveries and achievements that are used to detect and prevent it. Clearly, then, these drugs do not cure this social illness, but on the contrary they only expand and strengthen, which confirms that the diagnosis is wrong and that it is necessary to re-establish and prescribe new medicines according to it.

The aim of this paper is to substantially prove the above rule. As an example to confirm this is the period of the empire of the second righteous khalifa Omar El-Hattaba, RA, a ruler who is known as an example of justice and righteousness throughout the history of mankind, and his state and rule, which he established, is a true and real example of an ideal state that was only a natural consequence of the implementation of the Islamic preventive system, correct diagnosis of this wicked social disease, and the prescription of appropriate drugs that prevented and protected its occurrence and epidemic.

Keywords: justice, corruption, Islam, politics, prevention, power, control. 
الأستاذ الدكتور سليمان توبولياك

جامعة بيهاتش

كلية التربية الإسلامية

sulejman.topoljak@hotmail.com

الوسائل الوقائية لمواجهة الفساد والرشاوي في السياسة وممارسة الوظائف الحكومية في فلسفة عمربن الخطاب

\section{الخلاصة}

مشكلة الفساد في الدوائر الحكومية والوظائف العامة قديمة قدم البشر والحضارة

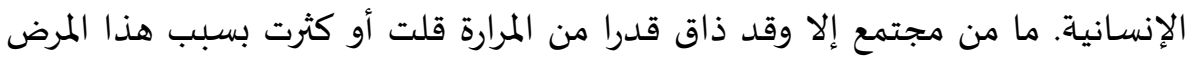

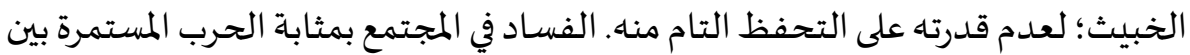

الخير والعدالة والموضوعية والنظام من جهاة وبين الشر والظلم والتحيز من جهاة أخرى.

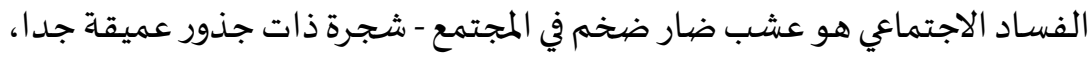

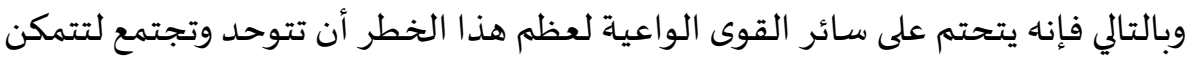
من قمع هذا الشر من جذوره من أجل حماية البشرية من ثمراتها القاتلة.

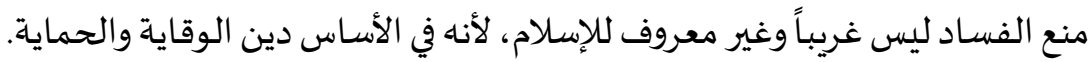
والهدف الأسـاسي للإسلام هو دعوة الناس وتشجيعهم على الخير وردعهم عن الشر وحفزهم على الابتعاد منه وترك الخطيئة.

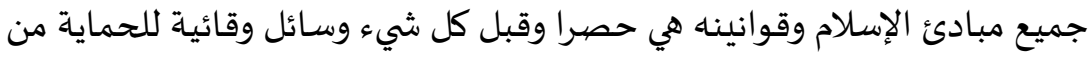

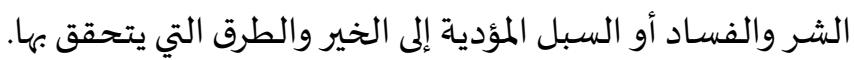

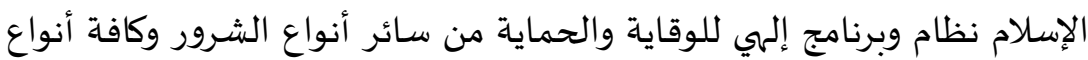
الفسـاد، الذي يضمن تطبيقه منع الفساد والقضاء عليه. النظر إلى مستوى الفساد وقياساء في مجتمع ما، أو شعب من من الشعوب أو أو مؤسسة

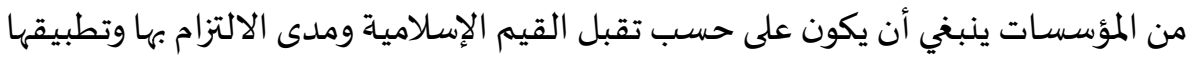

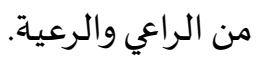

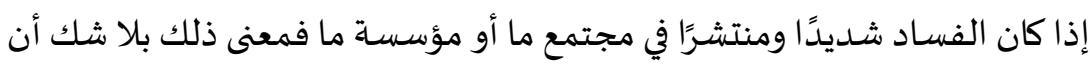

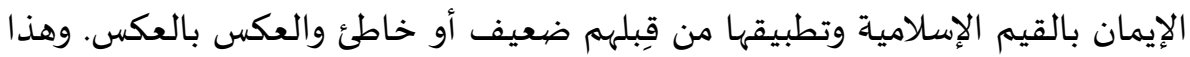


يصدقه وبكل وضوح الحالة الراهنة للعالم الفاسـد بشكل عام، ولا سيما العالم الإسلامي

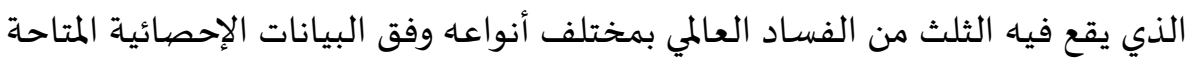
لأولئك الذين تعاملوا مع هذه القضية.

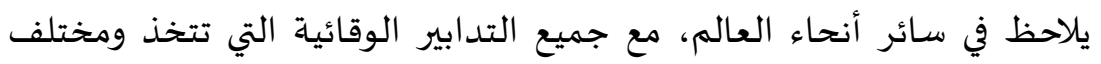

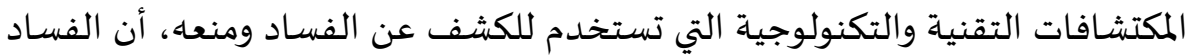

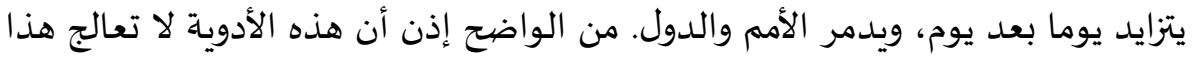

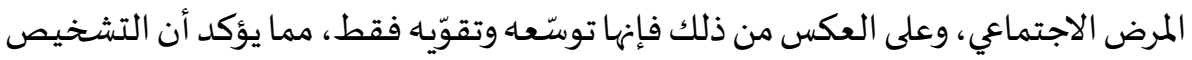

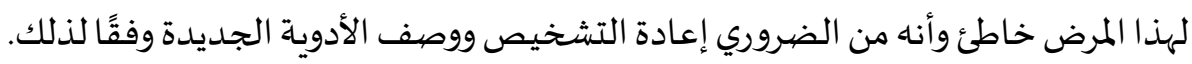

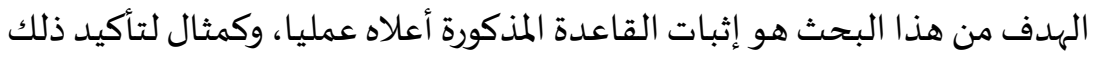
أخذت فترة الحكم للخليفة الراشد الثاني عمر بن الخطاب، رضي الله عنها، الحاكم الذي أنيان

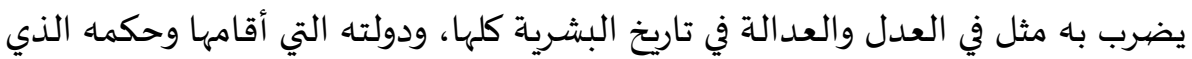

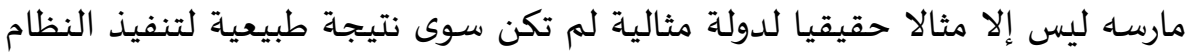
الوقائي الإسلامي، أي التشخيص الصحيح لهذا الإسيقا المرض الاجتماعي الشرير، ووصف الأدوية

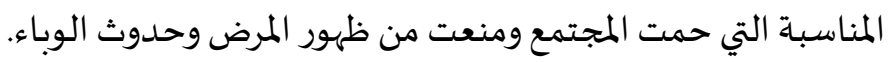

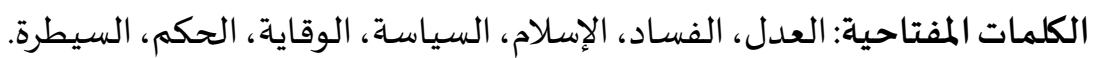

